\title{
Effect of mechanical disturbances on nematode communities in arable land
}

\author{
M. BRMEŽ, M. IVEZIĆ, E. RASPUDIĆ
}

\author{
University of Josip Juraj Strossmayer in Osijek, Faculty of Agriculture in Osijek, Trg sv. Trojstva 3, 31000 Osijek, \\ Croatia, E-mail:mirjanam@pfos.hr
}

\begin{abstract}
Summary
Nematode communities were used as bioindicators of changes in agroecosystems caused by anthropogenic factors. The aim of this study was to examine the impact of plowing and harrowing on nematode communities structure in comparison to "no tillage" treatments. The effects of mechanical disturbing of nematodes were determined on four soil treatments. Differences in nematode community structure were compared between two tillage regimes: standard tillage and no tillage. Research was conducted in 2000, in Kneževo near Osijek. Plowing had impact on increasing of bacterivorous nematodes and decreasing of fungivorous nematodes. Pratylenchus, Helicotylenchus and Tylenchus were dominant plant-feeding nematodes in no tillage treatments, while in plowing treatments Pratylenchus and Tylenchus were dominant. Abundance of Aphelenchoides decreased significantly after plowing. Tillage affected nematode communities in the soil ecosystem by changing the trophic structure and gave a decreasing, but not statistically significant, trend in MI.
\end{abstract}

Key words: nematode communities; bioindicators; mechanical disturbances

\section{Introduction}

In numerous studies, nematode communities showed possibilities to be good indicators of different kind of disturbances in ecosystems. Some groups of nematodes can survive under disturbed environmental conditions, while others can not. There are differences in feeding behavior (Yeates et al., 1993), and predominantly, omnivore and predators have great sensitivity to disturbances (Bongers et al., 1991; Bongers et al., 1995). Nematodes can be classified upon many different criteria, but the development of Maturity index (MI) (Bongers, 1990) presents a significantly advanced tool for predicting ecological processes in soil ecosystems. Above that, they play a great role in soil nutrient cycle, especially free-living nematodes (Ferris \& Matute, 2003; Neher, 2001). For those reasons, nematode communities have potential to serve as very good biotic indicators of soil processes. Structure of nematode communities can reflect differences in agroecosystem conditions (Ivezic et al., 2000), organic amendments (Goede, 1993; Goede \& Dekker, 1993; Sohlenius \& Wasilewska, 1984), heavy metal compounds (Korthals, 1997), soil tillage system (Hendrix et al., 1986; Sohlenius et al., 1987; Freckman \& Ettema, 1993; Neher \& Campbell, 1994), air pollution (Zullini \& Peretti, 1986; Steiner, 1994 a, b, c) river pollution (Zullini, 1976), and different kind of environmental monitoring (Bongers \& Ferris, 1999).

The objective of this investigation was to determine changes in nematode communities structure after human intervention or specific mechanical disturbances caused by tillage practices in eastern part of Croatia.

\section{Materials and Methods}

Research was conducted in 2000, in Kneževo near Osijek $\left(45^{\circ} 32^{\prime} \mathrm{N}, 181^{\circ} 44^{\prime \prime} \mathrm{E}\right)$, on caltic chernozem. The soil was a filty loam: $\mathrm{pH}\left(\mathrm{H}_{2} \mathrm{O}\right)=8.6 ; \mathrm{pH}(\mathrm{KCl})=7.53 ; \mathrm{Al}\left(\mathrm{P}_{2} \mathrm{O}_{5}\right)=$ $18.7 \mathrm{mg} / 100 \mathrm{~g}$ of soil; $\mathrm{Al}\left(\mathrm{K}_{2} \mathrm{O}\right)=28.42 \mathrm{mg} / 100 \mathrm{~g}$ of soil; $\mathrm{CaCO}_{3}=2.12$ and an organic content of $2.61 \%$. The arable treatments had been in place for at least 50 years before nematode sampling began, and all received similar fertilizers applications. The nematode communities were investigated on four different field treatments:

I. Treatment - arable land, without vegetation, no tillage regime. Treatment was predicted for corn, which should be sown in spring 2001. Previous culture was winter wheat, also in no tillage regime, harvested in July 2000. The no tillage regime involved sowing by direct drilling. In the sampling period, treatment was still without vegetation. First sampling was on $11^{\text {th }}$ of October 2000, while second was on $6^{\text {th }}$ of November 2000.

II. Treatment - arable land, without vegetation, standard tillage regimes. Treatment was predicted for corn which should be sown in spring 2001. The standard tillage regime included plowing to $30 \mathrm{~cm}$ and harrowing. Previous culture was winter wheat also in stan- 
dard tillage regimes. In the sampling period, treatment was still without vegetation. Plowing and harrowing were done on $12^{\text {nd }}$ of October 2000 . First sampling was on $11^{\text {th }}$ of October 2000 (before plowing), while second was on $6^{\text {th }}$ of November 2000 (after plowing).

III. Treatment - arable land, winter wheat, no tillage regimes. Treatment was soil under the winter wheat. Previous culture was corn, also in no tillage regime, harvested in September 2000. The no tillage regime involved sowing by direct drilling. Sowing date was $18^{\text {th }}$ of October. First sampling was on $11^{\text {th }}$ of October 2000 (before sowing), while second was on $23^{\text {th }}$ of November 2000 (after sowing).

IV. Treatment - arable land, winter wheat, standard regimes. Treatment was soil under the winter wheat. The wheat was sown on $18^{\text {th }}$ of October 2000. Previous culture was corn, also in standard tillage regime, harvested in September 2000. Standard tillage regimes included plowing to $30 \mathrm{~cm}$ and harrowing. Plowing and harrowing were on $12^{\text {nd }}$ of October 2000. First sampling was on $11^{\text {th }}$ of October 2000 (before plowing and sowing), while second was on $23^{\text {th }}$ of November 2000 (after plowing and sowing).

Sampling was done using a corer $\varnothing 2 \mathrm{~cm}$, to a depth of 20 $\mathrm{cm}$. There were 4 replicate plots of each treatment. Nematodes were extracted from $100 \mathrm{~g}$ subsamples of soil by the Seinhorst method (Seinhorst, 1956), at the Faculty of Agriculture in Osijek, in Laboratory of Nematology. Identification was done by using keys of Bongers (1994), Mai and Lyon (1975) and Andrassy (1984, 1988, 1993). Total number of nematodes and number of genera were determined and compared between treatments and tillage regimes, as well as Maturity index (MI), Plant parasitic index (PPI) and PPI/MI (Bongers, 1990; Bongers et al. 1997). Trophic structure was determined according to Yeates et al., 1993. The data were analyzed statistically, using ANOVA and LSD test on computer program Statistica by Vukadinović (Vukadinović, 1985; 1986).

\section{Results and Discussion}

Nematode communities were studied in four different treatments, on two occasions. Minimum abundance of nematodes was 138 nematodes/100 g soils in II. treatment before plowing, while the maximum was 1037 nematodes/ $100 \mathrm{~g}$ of soil in the same treatment after plowing. Average abundance of nematodes in treatments is shown in Fig.1.

Total number of nematodes in all treatments increased after plowing and sowing, with nematodes from c-p group 1 increasing after disturbances. Statistically significant differences in total number of nematodes occurred between sampling periods, but not between treatments.

In this experiment 41 genus were determined. A checklist of genera is presented in Tab 1.

The average number of genera occurring in each treatment is shown in Fig. 2. In no tillage treatments there were no significant changes in the number of genera between the

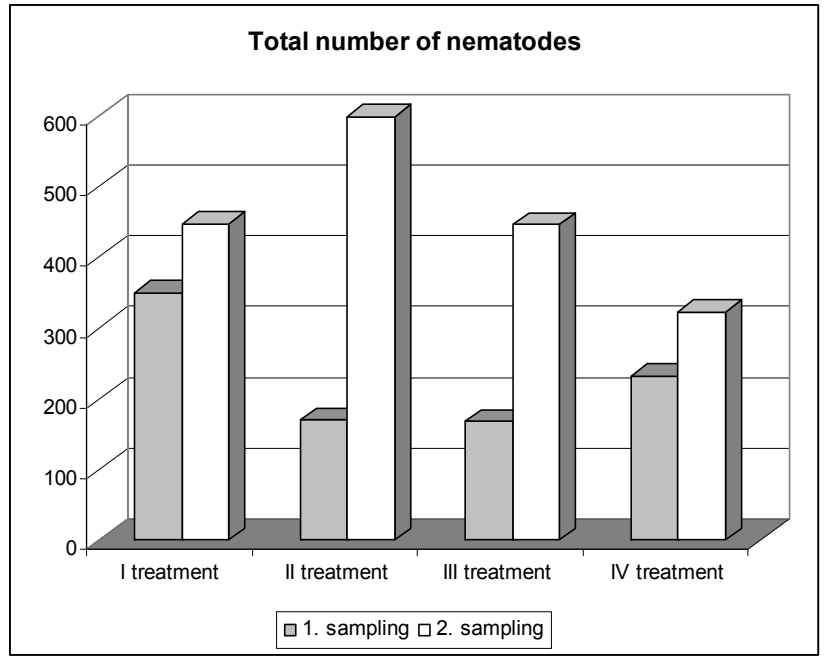

Fig. 1. Total number of nematodes in four different treatments in two sampling occasions

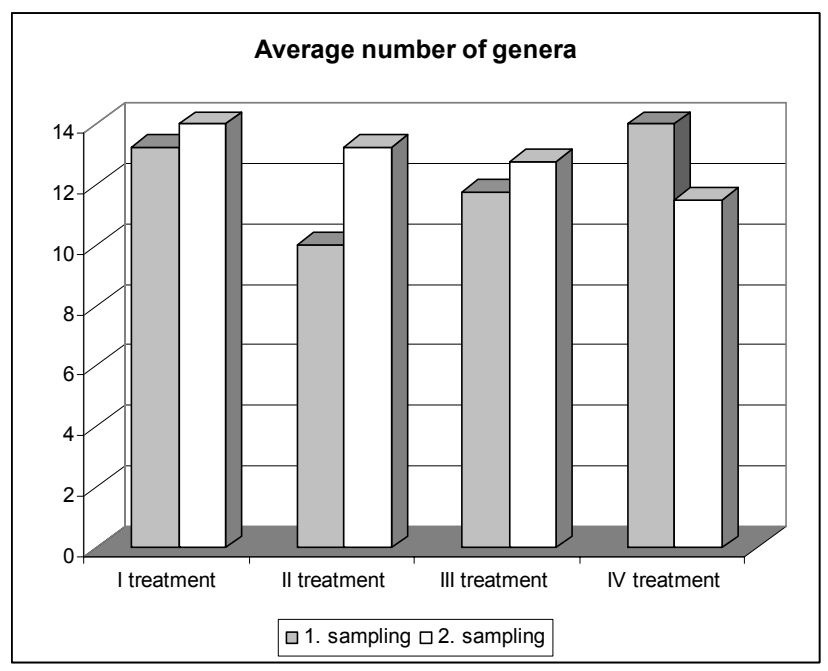

Fig. 2. Average number of genera occurred in each treatment on two sampling occasion

two sampling occasions. In treatment with standard tillage regimes (II. treatment), the number of genera increased a mean of 3 genera after plowing and sowing, while under wheat with standard tillage (IV. treatment) they decreased. Pratylenchus, Helicotylenchus and Tylenchus were the dominant genera in no tillage treatments. In standard tillage treatments Pratylenchus and Tylenchus were dominant. Aphelenchoides decreased in number after plowing, while Mesodorylaimus (which is an omnivorous nematode and thus sensitive to disturbance) occurred in same number after mechanical disturbances. Fiscus \& Neher (2002) found Aphelenchus, the most sensitive to direct effect of tillage. However they found Epidorylaimus and Tylencholaimellus tolerant, as well as Anatonchus, Clarkus, Mylonchulus and few others.

Trophic structure analyses showed similar patterns in all treatments investigated. Five trophic groups occurred (bacterivorous, fungivorous, plant-feeding nematodes, omnivo- 
Table 1. Check list of genera occurring in the 4 treatments on each sampling occasion

\begin{tabular}{|c|c|c|c|c|c|c|c|c|}
\hline \multirow{2}{*}{ Genus } & \multicolumn{2}{|c|}{ I. Treatment } & \multicolumn{2}{|c|}{ II. Treatment } & \multicolumn{2}{|c|}{ III. Treatment } & \multicolumn{2}{|c|}{ IV. Treatment } \\
\hline & 1. sampling & 2. sampling & 1. sampling & 2. sampling & 1. sampling & 2. sampling & 1. sampling & 2. sampling \\
\hline Acrobeles & - & - & - & - & + & + & - & - \\
\hline Acrobeloides & + & + & + & + & + & - & - & + \\
\hline Acrolobus & - & - & - & - & - & - & + & - \\
\hline Alaimus & - & + & + & - & - & - & + & - \\
\hline Aphelenchoides & + & + & + & + & + & + & + & + \\
\hline Aphelenchus & + & + & + & + & + & + & + & + \\
\hline Aporcelaimellus & - & - & - & - & - & - & - & + \\
\hline Cephalobus & + & + & - & + & - & + & + & - \\
\hline Chiloplacus & + & + & + & + & + & + & + & + \\
\hline Diploscapter & + & + & + & + & - & + & + & + \\
\hline Ditylenchus & + & + & + & + & + & + & + & + \\
\hline Dorylaimidae & - & - & + & - & - & - & - & - \\
\hline Dorylaimellus & - & - & - & - & + & - & - & - \\
\hline Enchodelus & - & + & - & - & - & + & - & + \\
\hline Eucephalobus & + & + & + & + & + & + & + & + \\
\hline Eudorylaimus & - & + & - & - & - & + & - & + \\
\hline Euteratocephalus & - & - & + & - & - & - & - & - \\
\hline Filenchus & - & + & + & + & + & + & + & + \\
\hline Helicotylenchus & - & + & + & + & + & + & + & + \\
\hline Heterocephalobus & - & - & - & - & - & - & + & - \\
\hline Heterodera & - & - & + & - & - & - & + & - \\
\hline Malenchus & - & + & - & - & + & + & + & - \\
\hline Mesodorylaimus & - & + & + & + & + & + & - & + \\
\hline Metateratocephalus & + & - & - & - & - & - & - & - \\
\hline Microdorylaimus & - & + & - & - & - & - & - & + \\
\hline Monhystera & - & + & - & - & - & - & - & - \\
\hline Mylonchulus & - & - & - & - & + & - & - & + \\
\hline Panagrellus & - & - & - & - & - & + & - & + \\
\hline Panagrobelus & - & + & - & - & - & - & - & - \\
\hline Panagrolaimus & - & + & - & - & - & + & + & - \\
\hline Paratylenchus & - & - & - & + & + & + & - & + \\
\hline Plectus & - & - & + & + & + & - & + & + \\
\hline Pratylenchus & + & + & + & + & + & + & + & + \\
\hline Prismatolaimus & + & + & + & + & + & - & + & + \\
\hline Psilenchus & + & - & - & - & - & - & - & - \\
\hline Pungentus & - & - & - & - & - & - & + & - \\
\hline Rhabditis & + & + & + & + & & + & + & + \\
\hline Rotylenchus & - & - & - & + & + & + & + & + \\
\hline Tylencholaimellus & + & - & - & - & - & - & - & - \\
\hline Tylenchorhynchus & + & + & + & + & + & + & + & + \\
\hline Tylenchus & + & + & + & + & + & + & + & + \\
\hline
\end{tabular}

rous and predators). Plant - feeding nematodes were dominant in all treatments, before and after disturbance. Bacterial and fungal feeding nematodes were the next most abundant groups. Omnivorous nematodes were present at 0 $-4 \%$ while predators were found in treatments III and IV with one specimen in each. Trophic structure presented in Fig. 3.

Plowing increased the proportion of bacterial feeding nematodes (treatments II and IV) and decreased plant feeding nematodes (treatment II). Similarly, Parmelee and Alston
(1986) found greatest number of plant feeding nematodes in treatments with minimum tillage, contrary to treatments with standard tillage regimes.

Fungal feeding nematodes decreased in number after plowing, genus Aphelenchoide decreased significantly in number. Omnivores were present $0-1 \%$, except in I treatment (soil without vegetation with no tillage regimes) when they occurred $4 \%$.

Results of MI, PPI and PPI/MI analyses, average abundance, average genera richness, as well as statistic analyses are 
Table 2. Average of MI, PPI, PPI/MI, total number of nematodes and number of genera in both sampling occasions with LSD test

\begin{tabular}{|c|c|c|c|c|c|c|}
\hline Sampling occasion $(\mathrm{A})$ & Treatments (B) & MI & PPI & PPI/MI & $\begin{array}{l}\text { Total number } \\
\text { of nematodes }\end{array}$ & $\begin{array}{c}\text { Number of } \\
\text { genera }\end{array}$ \\
\hline \multirow[t]{4}{*}{ 1. sampling } & I treatment & 1.625 & 2.825 & 1.825 & 350 & 13 \\
\hline & II treatment & 1.925 & 2.325 & 1.275 & 170 & 10 \\
\hline & III treatment & 2.225 & 2.675 & 1.25 & 168 & 12 \\
\hline & IV treatment & 1.9 & 2.625 & 1.45 & 232 & 14 \\
\hline Average 1 sampling occasion & & 1.919 & 2.613 & 1.45 & 230 & 12 \\
\hline \multirow{4}{*}{ 2. sampling } & I treatment & 2.175 & 2.775 & 1.35 & 359 & 14 \\
\hline & II treatment & 1.575 & 2.55 & 1.7 & 599 & 13 \\
\hline & III treatment & 1.85 & 2.75 & 1.55 & 446 & 13 \\
\hline & IV treatment & 1.875 & 2.9 & 1.6 & 323 & 12 \\
\hline Average 2 sampling occasion & & 1.869 & 2.744 & 1.55 & 432 & 13 \\
\hline LSD 5\% (A) & & n.s. & n.s. & 0.9074 & 127.2928 & n.s. \\
\hline LSD $1 \%(\mathrm{~A})$ & & n.s. & n.s. & n.s. & n.s. & n.s. \\
\hline LSD 5\% (B) & & n.s. & 0.1116 & n.s. & n.s. & n.s. \\
\hline LSD 1\% (B) & & n.s. & 0.1529 & n.s. & n.s. & n.s. \\
\hline LSD $5 \%\left(A^{*} B\right)$ & & 0.3809 & 0.2566 & 0.2659 & n.s. & 2.9595 \\
\hline LSD $1 \%\left(A^{*} B\right)$ & & 0.5922 & n.s. & 0.3809 & n.s. & n.s. \\
\hline
\end{tabular}

n.s. - not statistically different; A - sampling occasion; B - treatments

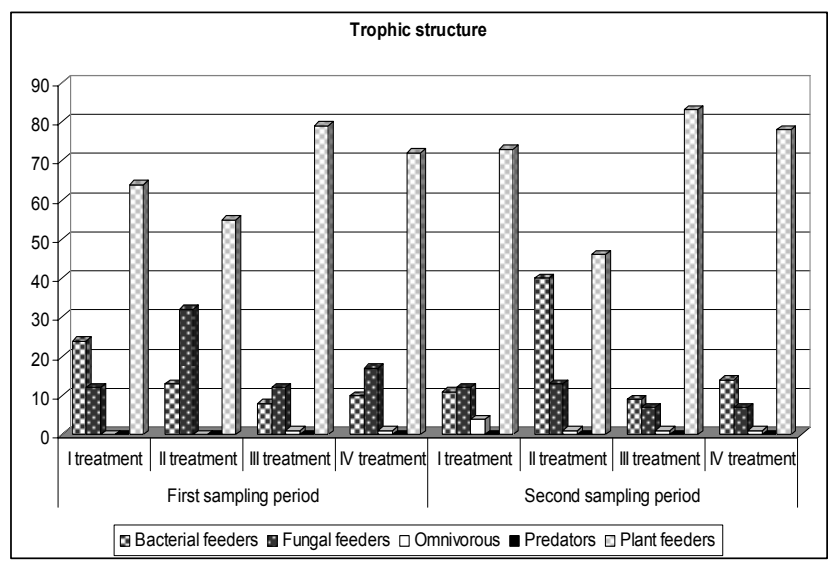

Fig. 3. Trophic structure in each sampling occasion

presented in Table 2 .

The average MI index was affected by plowing, decreasing from 1.925 to 1.575 in II treatment, and from 1.9 to 1.875 in IV treatment. PPI also demonstrates the change in nematode communities by the increase in value after disturbance in treatments with standard tillage regimes. After plowing, in second sampling occasion PPI/MI showed the more disturbed environment in standard tillage regimes (1.7 in II. treatment and 1.6 in IV. treatment) in comparison to no tillage regimes (1.3 in I. treatment and 1.5 in III treatment). Although MI, PPI and PPI/MI do not show statistically significant differences among treatments and sampling occasions, the trends in them do represent an effective tool as distinguishing parameters in tillage regimes under our conditions. However, some authors obtain different results (Villenave et al., 2001).

\section{Conclusion}

Plowing had an impact on the increase of bacterial feeding nematodes and on decrease of fungal feeding nematodes. Pratylenchus, Helicotylenchus and Tylenchus were dominant plant parasitic nematodes in no tillage treatments, while in plowing treatments Pratylenchus and Tylenchus were dominant. Genus Aphelenchoides decreased significantly after plowing. Effect of tillage did affect nematode communities in the soil ecosystem by changing the trophic structure and decreasing of MI.

\section{Acknowledgement}

The investigations are supported by the Ministry of Science and Technology in Croatia (Project - 079024).

\section{References}

ANDRASSY, I. (1984): Klasse nematoda. Gustav Fisher Verlag, Stuttgart, pp. 509

ANDRASSY, I. (1988): The superfamily Dorylamoidea (Nematoda) - a review of Family Dorylaimidae. Opus. Zool. Budapest, 23: $3-63$

ANDRASSY, I. (1993): A taxonomic survey of the family Mononchidae (Nematoda). Acta Zool. Hung., 39: 13 - 60

Bongers, T. (1990): The Maturity index: an ecological measure of environmental disturbance based on nematode species composition. Oecologia, 83: $14-19$

Bongers, T., AlKemade, R., YeATES, G. W. (1991): Interpretation of disturbance-induced maturity decrease in marine nematode assemblages by means of the maturity index. Mar. Ekol. Prog. Ser., 76: 135 - 142 
Bongers, T. (1994): De nematoden van Nederland. KNNV: Utrecht. pp. 408

Bongers, T., De Goede, R. G. M., Korthals, G. W. \& YeAtes, G. W. (1995): Proposed changes of c-p classification for nematodes. Russian J. of Nem., 3: $61-62$

Bongers, T., Van der Meulen, H., Korthals, G. W. (1997): Inverse relationship between the nematode maturity index and plant parasite index under enriched nutrient conditions. Appl. Soil Ecol., 6: 195 - 199

BONGERS, T., FERrIS, H. (1999): Nematode community structure as a bioindicator in environmental monitoring. Trends in Ecology \& Evolution, 14: 224 - 228

FERris, H., MATUTE, M. M. (2003): Structural and functional succession in the nematode fauna of a soil food web. Applied Soil Ecology, 23: 93 - 110

Freckman, D. W., EtTema, C. H. (1993): Assessing nematode communities in agroecosystems of various human intervention. Agriculture, Ecosystem and Environment, 45: $13-22$

FISCUS, D. A., NEHER, D. A. (2002): Distinguishing sensitivity of free living soil nematode genera to physical and chemical disturbances. Ecological Applications, 12: 565 575

De Goede, R. G. M. (1993): Terrestrial nematodes in a changing environment. Thesis, Wageningen Agricul. Univ., 138

De Goede, R. G. M., DeKKer, H. H. (1993): Effects of liming and fertilization on nematode communities in coniferous forest soils. Pedobiologia, 37: 193 - 209

Hendrix, P. F., Parmelee, R. W., Crossley, D. A. JR., Coleman, D. C., Odum, E. P., Groffman, P. M. (1986): Detritus food webs in conventional and no-tillage agroecosystems. BioScience, 36: $374-380$

IVEZIĆ, M., RASPUDIĆ, E., BRMEŽ, M. (2000): Structure of nematode communities in different agroecosystems in Croatia. Helminthologia, 37: 165 - 169

Korthals, G. (1997): Pollutant-induced changes in terrestrial nematode communities. Thesis Landbouwuniversitet Wageningen: pp. 107

MAI, W. F., LYON, H. H. (1975.): Pictorial key to genera of plant-parasitic nematodes. Cornell University Press. London: pp.219
NEHER, D. A. (2001): Role of nematodes in soil health and their use as indicators. J. Nematology, 33: $161-168$

NeHER, D. A., CAMPBELL, C. L. (1994): Nematode communities and microbial biomass in soils with annual and perennial crops. Applied Soil Ecology, 1: $17-28$

Parmelee, R. W., Alston, D. G. (1986.): Nematode trophic structure in conventional and no-tillage agroeco-systems. J. Nematol., 18: 403 - 407

SOHLENIUS, B., WASILEWSKA, L. (1984): Influence of irrigation and fertilization on the nematode community in a Swedish pine forest soil. J. Applied Ecol., 21: 327 - 342

Sohlenius, B., Bostrom, S., SANDOR, A. (1987): Longterm dynamics of nematode communities in arable soil under four cropping systems. J. Applied Ecol., 24: 131 - 144 STEINER, W. A. (1994a): The influence of air pollution on moss-dwelling animals: Methodology and composition of flora and fauna. Rev. Swis. Zool., 101: 533 - 556

SteINER, W. A. (1994b): Aquatic fauna with emphasis on on Nematoda and Tardigrada. Rev. Swis. Zool., 101: $699-$ 724

STEINER, W. A. (1994c): Seasonal and long-term fluctuations on Rotifer, Nematode and Tardigrada populations. Rev. Swis. Zool., 101: 1017 - 1031

Villenave, C., Bongers, T., Ekschmitt, K., DJigal, D., Chotte, J. L. (2001): Changes in nematode communities following cultivation of soils after fallow periods of different length. Applied Soil Ecology, 17: 43 - 52

VuKADINOVIĆ, V. (1985): The use of microprocessors in regression analysis. Znan. Prak. Polj. Tehnol., 15: $279-$ 298

VuKADINOVIĆ, V. (1986): Determination of functional dependence by microprocessor. Znan. Prak. Polj. Tehnol., 16: $371-387$

YeAtes, G. W., Bongers, T., De Goede, R. G. M., FrecKMAN, D. W., GeOrGIEVA, S. S. (1993): Feeding habits in nematode families and genera - An outline for soil ecologists. J. Nematol., 25: 315 - 331

ZULLINI, A. (1976): Nematodes as indicators of river pollution. Nematologica Mediteranea, 4: 13 - 22

Zullini, A., PERETTI, E. (1986): Lead pollution and mossinhabiting nematodes of an industria area. Water, Air and Soil Pollution, 27: 403 - 410 